ABSTRACT

The Disenchantment of the Wonderful - A Doll's House and the Idealist Imagination

During the course of the nineteenth century, the notion of imagination underwent a radical redefinition. From being the highest, divine, power of man to being subjected to a growing pathologization and degradation, the redefinition of imagination played a central role in the transition from idealism and romanticism to the emerging modernism and realism. Henrik Ibsen's $A$ Doll's Hous (1879) may be read into this particular context with its 'disenchantment' of the 'wonderful' - a word which Georg Brandes termed the very keyword of roman-

ticism.

Focusing on the specific Scandinavian context, where idealist aesthetics continued to be particularly strong, I will examine $A$ Doll's House from the perspective of the contemporary spectator in the context of an on-going Nordic aesthetic dispute. The contemporary Scandinavian reviews will serve to bear evidence of this dispute. In the article, I analyse how the play thematizes imagination and employs recurrent references to idealist culture in order to disenchant the romantic imagination of the wonderful. The analysis will focus in particular on the representation of the characters of Nora and Helmer, but also comes to implicate the spectator of the play.

Keywords: imagination, Henrik Ibsen, Idealism, Romanticism, philosophy.

BIOGRAPHY

Ulla Kallenbach holds a PhD (2014) in Arts and Cultural Studies from the University of Copenhagen, Denmark, where she is currently External Lecturer. She received her MA in Text and Performance in 2005 (Royal Academy of Dramatic Arts (RADA) / King's College London) and an MA in Theater Studies in 2007 (University of Copenhagen) with the prize dissertation Space and Visuality in the Drama Text. Her primary fields of research deal with the cultural history of imagination in philosophy and drama as well as various aspects of dramaturgy. She is a board member of the Association of Nordic Theatre Scholars and is presently the Co-Editor of Nordic Theatre Studies.

kallenbach@hum.ku.dk

\section{The Disenchantment of the Wonderful - A Doll's House and the Idealist Imagination}

\author{
ULLA KALLENBACH
}

Its famous afterlife as a trailblazing feminist play has somewhat overshadowed a view of $A$ Doll's House as a response to the era that preceded it. When $A$ Doll's House was first performed at the Royal Theatre in Copenhagen, 21 December 1879, it was not only Nora's famous exit that was debated. More than solely a feminist attack on a patriarchal, authoritarian society, the play was - also - seen as a confrontation with the romantic, idealist culture that had dominated the nineteenth century. In the following, I will seek to examine $A$ Doll's House from the perspective of the contemporary spectator in the context of an on-going Scandinavian aesthetic and ideological dispute concerning the transition between the romantic idealist and the modern conception of imagination that took place in the nineteenth century. The course of the nineteenth century had seen a drastic ideological and aesthetic re-evaluation, and the notion of imagination played a central part in this process. It thus seems relevant to look closer at how this redefinition of imagination is adressed in this play, which deals with many aspects of imagination such as make-believe, pretence, masquerading and, notably, the collapse of the fantasy of the "wonderful".

Consulting the Danish and Norwegian reviews of the publication and Scandinavian premieres of the play will bear evidence of this ideological and aesthetic dispute, being as they are both observers of and partakers in the cultural debate, as well as provide us with a view of the play's impact on its audience. These reviews provide the starting point of my analysis of the play, which will focus on the rep-

resentation of the characters of Nora and Helmer. Idealism runs as an underlying current that dominates the century stretching from Immanuel Kant's so-called "Copernican revolution" to the modern breakthrough. The context of Idealism in relation to Ibsen has been explored in Toril Moi's Henrik Ibsen and the Birth of Modernism (2006). Moi, in her analysis, focuses on German Idealism, especially that of Friedrich Schiller. The Scandinavian context is distinct, however, from the European in its strong focus on the idyllic and harmonic. Furthermore, Scandinavian Idealism was incarnated in various forms such as the natural philosophy of Henrich Steffens (1773-1845), the National Romanticism of "Nordic Poet King" Adam Oehlenschläger (1779-1850), and in the Hegelian aesthetics of authoritarian arbiter of taste Johan Ludvis Heiberg (1791-1860). The current of Idealism bore a strong influence, permeating aesthetic, religious and philosophical thought. Even in the late 1870s, idealist aesthetics was still dominant. This was also evident in the theatrical repertoire.

In the following, I will first introduce key aspects of imagination in a Scandinavian idealist context, and the reversal in the appraisal of imagination illustrated e.g. in Georg Brandes' illustrative analysis of Oehlenschläger's play Aladdin or the Wonderful Lamp (Aladdin, eller Den forunderlige Lampe, 1805) and Ibsen's Peer Gynt (1867). This will provide the background for an analysis of imagination in $A$ Doll's House, where I argue that a similar reversal can be observed. 


\section{THE IDEALIST IMAGINATION}

The concept of imagination has long been an overlooked aspect in studies of both performance and of the drama text and a precise definition of imagination is still elusive. Originially derived from the Latin imaginatio (of imago, image) translated from Greek Phantasia (of phantazein, making visible, phantasma, mental representation), imagination had since Aristotle, whose influence was strikingly durable, signified a capacity to form mental images and was thus conceived as a reproductive faculty, which "mirrored" the sensible world in mental images. In the context of Idealism and Romanticism, however, the concept of imagination has a specific cultural and ideological significance as a productive or creative force of man, as suggested in the German terms Einbildungskraft or Vorstellungskraft. Rather than a mirror, imagination would be conceived as a "lamp"; a force of divine origin casting its inner light onto its object.

It was precisely the concept of imagination, Einbildungskraft, which was at the heart of Kant's "Copernican revolution", which was launched with the Critique of Pure Reason (1781). Here Kant redefined imagination as a productive force, a transcendental power. Hence, imagination would become recognized as the essential prerequisite of knowledge. In the Critique of Pure Reason, Kant would also set up a fundamental rift between subject and object. The subject can never experience an object as it is, "Das Ding an sich", but only as it is experienced, i.e. as processed by the mind. The imagination would be the central medium for allowing this process to occur, not only in reproducing sensory experience, but in synthesizing sensation and understanding, producing the "rules" allowing for the comprehension of experience.

This redefinition of imagination would later allow for the Romantic, Idealist veneration of the genius, since only the (poetic) natural genius was believed to be able to exercise the full potentials of imagination. Only the genius could, through these potentials, access the ideal world of infinity. In the Idealist aesthetics, the purpose of art is to reveal a higher truth, the ideal that lies beyond mere perception. ${ }^{2}$ Imagination was thus considered capable of accessing a truth beyond the truth, that of reason. Thus, in 1833, Norwegian poet Nicolai Wergeland (1780-1848) wrote in a defence of his son Henrik Wergeland's (1808-45) poetry: "A sublime Imagination! Three or four, in a prosaic sense widely different, objects in one merging, to be conceived by the same capacity that created it, by Imagination, but impossibly by Reason." ${ }^{3}$

For Idealism, imagination was a means of connecting with the ideal, an ideal reality, free from the constraints of the material reality, which was only a faint reflection of the ideal. Hence, also the Romantic fascination with the exotic and fantastic . In idealist aesthetics, art goes beyond mere representation; accordingly, Danish philosopher F. C. Sibbern (1785-1872) can describe a "double idealization" in which the Ideal is represented in an ideal manner. An idea which we also find in the works of one of the most influential and dominant figures in Danish theatre and cultural life of the Golden Age, Johan Ludvig Heiberg, whose adoptation of Hegelian aesthetics had a marked emphasis on unity, idealization and harmonization. Principally, this was to be made visible in the formal qualities of the artwork, the conformance of the infinite with the finite, which should be "Reality idealised, since it would otherwise not be poetry".

With the veneration of the ideality of art, it, like religion, becomes a means of refining man. Thus, for Oehlenscläger, the purpose of art is to nurture the soul: "to give nourishment to the soul by a true holy Communion." A view that was reiterated at the celebration of Oehlenschläger's $100^{\text {th }}$ birthday on 14 November 1879, in philosopher Professor, Dr. Rasmus Nielsen's (1809-84) commemorative speech: "It is the Poet's Word, the Word of Imagination that gives wings to the Soul" 7 Art was thus a vehicle, or "lamp" as described above, for letting the divine light of the ideal shine out onto the beholder. The idea of a divine relation between ideality and art was thus still persistent when A Doll's House was first performed. Accordingly, Norwegian professor and theologian Fredrik Petersen (1839-1909) in his review stated: "Art is a child of the human being's creative gift in its highest ideality, the gift which takes him closest to divinity." However, the concept of the idealist imagination had been significantly contested, especially in the latter part of the nineteenth century.

\section{FROM ALADDIN TO PEER GYNT}

The Romantic veneration of the poetic genius was later analysed by Georg Brandes (1842-1927) in his 1886 essay on Adam Oehlenschläger and his orientalist play, Aladdin or the Wonderful Lamp (Aladdin, eller Den forunderlige Lampe, 1805). Aladdin to Brandes, represented not only the foundation upon which Danish literature in the first half of the nineteenth century was built. It was the foundation of Danish cultural life as such - nothing less than the "the poetic bible" of an entire era. ' Stating that "[i]n the common view, Aladdin signifies [...] the enthronement of Imagination" ${ }^{10}$ Brandes defines the romantic imagination as "the poetic inventiveness", the free, creative invention that was "the watchword of Romanticism". ${ }^{11}$ When describing the influence of the figure of Aladdin in Danish culture, Brandes chose the image of light, not only of a lamp, but of a gigantic lighthouse to describe the immense impact of Oehlenschläger's character "There he stands, this Aladdin, with the radiant lamp held high in his hand, the formative figure of Denmark's entire intellectual life in this century, like a gigantic light-bearing statue illuminating the entrance to a harbour." ${ }^{12}$ While Brandes did hold Aladdin in high regard, his analysis places it in a context of which he is markedly critical, namely the context of Romanticism and Idealism. Accordingly, the character of Aladdin, in Brandes' perspective, is also the personification of the naïve, free poetic spirit that is characteristic of Danish as well as Nordi Biedermeier Romanticism.

While we should be cautious of Brandes' bias, the reversal in the view of imagination that he describes is notable. The counter-figure to Aladdin Brandes found in the plays of Ibsen, in particular in Peer Gynt: "The polar opposite to Aladdin is Per Gynt [sic]. Like Aladdin is the glorification of imagination, Per Gynt is the declaration of war against it. To Oehlenschläger the life of imagination is the grandest, to Ibsen the most dangerous and indeed degrading of all. The imagination is Aladdin's bliss and cause of his genius; it is Per Gynt's misery and causes his wretchedness. The very same power, which to Oehlenschläger is truth and life, is to Ibsen the lie that evades life."13

Imagination has, states Brandes, been entirely reevaluated: "for the same, which in Aladdin is the beautiful dream is in Per Gynt the loathsome delusion." ${ }^{14}$ The opposition that Brandes sets up here between Aladdin and Peer Gynt is illustrative of the development in the understanding of imagination that took place in the nineteenth century. From wonderful dream and ideal truth to pathologization, fantastical escapism and illusory lies, from worship to degradation, imagination underwent a radical redefinition where the relation of imagination an reality was turned upside down. And the light of the lamp became connected with diversion rather than revelation. A key term is fantasteri, which can be translated as delusion or reverie, the fantast being the escapist, or the dreamer, disengaged with real life. This was the topic of Danish writer Hans Egede Schack's (1820-59) novel The Phantast (Phantasterne, 1857), a story of the coming of age of three young men, facing the negative consequenses of fantasying, from childhood's playful fantasies to adulthoods erotic fantasies and escapism, the pathological imagination and the inevitable confrontation with the demands of reality.

Søren Kierkegaard (1813-55) was one of the first philosophers to contest the idealist imagination, arguing: "The fantastic is generally that which leads a person out into the infinite in such a way that it only leads him away from himself and thereby prevents him from coming back to himself." The imagination, so to speak, becomes a flickering light that leads man astray, leading him away from himself. Kierkegaard too, defines imagination (Indbildningskraft) as idealization, as "the faculty of representing perfection (idealization)". ${ }^{16}$ However, since imagination is idealization it is alluring and therefore deceptive. While imagination can be positive force in its potential to save man from the pains of reality, there lies a danger in the liability of losing touch with reality and one's inner, true life altogether. Further, precisely because imagination can only idealize, its shortcomings become eviden when dealing with the sufferings of everyday life: 
"but suffering, on the other hand, is something the imagination cannot represent, except in a rendering which represents it as already perfected (idealized), that is, softened, toned-down, foreshortened." ${ }^{17}$ The wording here is in significant contrast to the romantic conception of imagination as an emanating, complete perfection. The ideal that imagination produces is, in fact, imperfection, since "the imaginary picture, that is, the picture which the imagination presents and fixes, is after all, in a certain sense, unreality, it lacks the reality of time and duration and of the earthly life with its difficulties and sufferings". ${ }^{18}$

The imagination of the Romantic Idealism became, as it were disenchanted. This disenchantmen also comes to mark the end of an ideological era, as Prophessor in Philosophy Richard Kearney describes it: "The collapse of imagination's dream before the encroaching realities of historical existence, is the point where romantic idealism ends and existentialism begins." ${ }^{19}$

The initial wave of enthusiasm for imagination inevitably led to an equal disillusionment. The "extravagant claims for man's creative power" ${ }^{20}$ that the romantic imagination had declared simply stood in such contrast to the modern industrialised, post-revolutionary reality that it could not be upheld. As Prophessor Richard Sha explains it, "one key reason why the imagination became pathologized was it potential to turn the mind within, away from engagement with the world". ${ }^{21}$

The relation between the real and the ideal thus becomes reversed and the ideal replaced by the imaginary, as an escapist inferior sphere that is in sharp contrast with reality. Accordingly, the relation of ar to reality is reversed too. In 1901, Brandes would describe this reversal of imagination as follows: "For a long time and in many countries imagination was regarded as a kind of giant spider which out of itsel spun figments of the brain in all sorts of beautifu figures; now it is probably rather conceived as a plant that draws all its nourishment from the earth wherein only it thrives: the poet's observations and experiences." ${ }^{22}$ No longer can art be conceived as conveying an otherworldly ideal, but must take its inspiration from the real life that the artist observes and, e.g. in Brandes' aesthetics, debates.

\section{A DOLL'S HOUSE BETWEEN REACTIONARY} IDEALISM AND PROGRESSIVE REALISM

The view of the play as a confrontation with the aesthetic and ideological values of the nineteenth century is also evident in the Scandinavian reviews of A Doll's House. ${ }^{23}$ As Edvard Brandes (1847-1931), brother of Georg Brandes, wrote: "A Doll's House i a contribution to the strife between the reactionaries in Denmark-Norway and progressive literature. It is a strike against those who believe that they can confine poetry within the barriers of conventiona morality." ${ }^{24}$ It was a blatant attack on social, cultural, religious and aesthetic values as such, here described by liberal journalist Erik Vullum (18591916): “A Doll's House is the individual's opposition against the demands of traditional religion and the way society is organised, carried out with a ruthles consequence which has never before been seen in our literature." ${ }^{25}$

A Doll's House became part of an on-going ideological polemic in which the reviewers were fa from neutral observers, but rather active partakers. For the progressive advocates of realism, these values were the ideas of the times gone by; ${ }^{26} \mathrm{val}$ ues which for the opponents of the play were still wholly of the present. ${ }^{27}$ What the positive reviewer commended was precisely what the negative reviewers condemned. So, while the favourable reviewers praised the triumph of realism and thus the defeat of Romantic Idealism, the critics reproached it. A the one end of the spectrum stood Helmer, along with 'the Helmers' of the bourgeois society, as femireview, ${ }^{28}$ the authority, the upholder of the idealis tenets; at the other end Nora, the child coming of age, rebelling against these principles; principles which were still far from defeated. As theatre historian Robert Neiiendam expressed it: "Ibsen stroke hard, because he cut in living flesh." ${ }^{29}$

So what principles and ideas did Ibsen strike out against and how does this relate to the conception of imaination? In the following I will an ly how the play thematizes imagination and employs recurrent references to idealist culture in order to 'disenchant' the romantic imagination, focusing in particular on the representation of the characters of Nora and Helmer.
THE DISENCHANTMENT OF IMAGINATION

In this context of an on-going cultural polemic the characters of Nora and Helmer were seen as symbols of recognizable societal characters, as observed by Vullum: "Helmer and Nora are individual figures, but at the same time they are typical and more than typical. There is something symbolic in them and about them, Helmer is an expression of external, vacuous authority, Nora is the opposition that breaks with this external authority, and however well this is covered, its symbolism eventually announces itself in our thoughts." 30

This symbolic dichotomy was also suggested in the Danish casting. The world's first Nora wa played by Betty Hennings (1850-1939), famou for her repertoire of the 'stock character' Leonora, the ingénue of Ludvig Holberg's comedies. To the contemporary spectator, this background was recognised in the initial childish characterization of Nora, but stood in stark contrast to the determined, mature Nora of Act III. ${ }^{31}$ In contrast, the role of Torvald Helmer was portrayed by Emil Poulsen (1842-1911), a classic romantic actor. Torvald Helmer is the personification of the idealist aesthete; noble, of high moral standards and refined taste. Traits that Poulsen emphasized in his portrayal of Helmer. Appearances and aesthetics, to Helmer, are key, already as layed out in Ibsen's opening stage directions. His home is carefully decorated. carpeted floors, engravings, books in fine bindings and the piano, an expensive item in the lawyer's bourgeois home. The Danish world premiere, directed by H. P. Holst (1811-93), emphasized the aesthetic idealism even further by displaying a bus of Venus in Helmer's bookcase and engravings of romantic icons such as Beethoven and Mozart (the quintessential Aladdinesque prodigy) hung over the piano. Above these images hung a copy of Raphael's Sistine Madonna (The Madonna Standing on Clouds with SS. Sixtus and Barbara, 1513-14), a painting, which had reached a cult-like status in Romanticism where it signified a particular poetic spirit of divine inspiration. ${ }^{32}$ Further, mahogany furniture and gilded branched candlesticks, statues and figurines along with a second bookcase with sheets of music also served to establish a home of refined taste. A similar strategy could be observed in the Swedish premiere, which featured figures of Goethe, Schiller and Ole Bull as well as Raphael's Sistine Madonna. The Christmas tree too was a potent social symbo that also had specific Idealist connotations. ${ }^{33}$

It was, however, a home with an attractiveness that reviewers recognized as a surface only, disengaged with reality, as described by Vullum: "Lawye Helmer is a typical representative for what we ordinarily understand by beauty; but with him, beauty is merely another expression of outward glitter, and that is the meaning of the word in most people's mouths. Beauty means the quasi-aristocratic withdrawal from the world with its needs, reality and democracy, beauty is life among attractively bound and tame books, Persian carpets, lamps and candelabra [...]. To embroider is lovelier than to knit, as Helmer says. But it is this interpretation of beauty, nobility and life's values that Henrik Ibsen has tried to break down in A Doll's House." 34 It should be noted here, how the reviewer exactly voices the dichotomy between on the one hand ideal, refined and notably disengaged beauty, which he sees as the standard, public attitude or life value, and on the other hand the call by Ibsen for a cessation of this

For those in favour of the play, Helmer was exposed as the personification of egoism. For Helmer Nora is not only a doll, or a toy, but an ideal dream or fantasy in which he takes pleasure and pride. The ideal that he sees in Nora is, however, nothing but a reflection of himself. He is infatuated with her beauty rather than in love with her. He will not have he eating macaroons lest they damage her teeth. She must dress up, play the part. This, Nora has done to perfection, playing the role of the ideal wife, cater ing for Helmer's idealist tastes. Behind this fantasy lies a desire for authority. Helmer shapes Nora in his image.

The theme of masquerading, the imagining and performing of roles and scenarios, lies recurren throughout the play. ${ }^{35}$ The third act masquerade at Stenborg's, obviously, takes on a pivotal role, the end of the masquerade marking the beginning of the $\mathrm{ca}^{-}$ tastrophe. But throughout the play, masquerading lies as the core of Helmer's and Nora's marriage, where Nora must take heed that there may come time when the masquerade is over, "when he's lost 
interest in watching me dance, or get dressed up, or recite." ${ }^{36}$ Nora plays the parts of first daughter then wife, as an actress adhering to the demands of the metteur-en-scène, first for her father then Helmer She lies to Helmer and flirts with Dr. Rank to keep up the appearance of the role that they desire her to play or to present the image that they wish to see in her. She must wear her dresses like costumes, put on the act of the squirrel, the skylark, the spendthrift, little Nora; she must put herself on show and dance in public for Helmer.

Nora's dancing, to Helmer, is an aesthetic fantasy. "The sensuality he shows at night is also that of the aesthetician: she is adorned, beautified and appeals to his fantasy as a stranger," wrote Edvard Brandes in his review. ${ }^{37}$ The dance that Nora rehearses in view of the audience and later performs at the upstairs masquerade out of view is the tarantella. Being an idealised expression of the essence of the Italian sensuality and vitality of peasant life, the tarantella in the nineteenth century was laden with cultural, aesthetic and historical connotations. In the public imagination, the tarantella was the quintessentia fantasy of idyllic merriment of the imaginary Italy that, amongst others, August Bournonville (180579) portrayed in his ballets, and which had become identical with Italy itself. A fantasy, which in Nora's rehearsal is the exact opposite: namely a desperate misperformance in face of the encroaching realities, a tarantella characterized by a kind of savageness incompatible with Helmer's idealistic aestheticism. In Nora'a misperformance of the tarantalla on stage, the idealized Italian fantasy is subverted for Helmer and the spectators alike.

The unseen, but audible, and therefore nevertheless present tarantella that Nora performs at Stenborg's masquerade is, in contrast, an aesthetically pleasing tarantella, 'Helmer's' tarantella. For Helmer, the aestheticised tarantella is the representation and arousal of his fantasies and desires. The Nora that Helmer desires is imaginary, an image, an idealised erotic fantasy: "It's because I'm pretending we are secretly in love, secretly engaged and nobody suspects there is anything between us." (p. 70). By letting this idealized fantasy remain, scenically, to be imagined, it also becomes the spectator's tarantell as much as it is Helmer's - to their aesthetic stand- ards, in their control. Here, via the activation of the imagination, the spectator's perspective is set up as analogous to Helmer's.

Nora, in light of Brandes' analysis of Aladdin, may be seen as an "Aladdinesque" character, characterized by Dr. Rank as a lykkebarn - (neither McFarlane's translation "Lady Luck" (p. 72) nor Fjelde's "Charmed life" (p. 102) ${ }^{38}$ manage to capture the Aladdinesque reference in the literal meaning "lucky-child" or "child of fortune") - naïve and impulsive and with a childlike ignorance of the crime she has committed. ${ }^{39}$ Nora is idealistic, too. She firmly, and rather childishly, believes in Torvald's ideals and in her fantasy of "det vidunderlige", "the wonderful", that will happen when Torvald will rise to save her in her hour of need. The Aladdinesque in Nora is, however, of a subversive nature. Nora lies, deceives and manipulates. Although her motives for forging her father's signature may have been out of love for Helmer, the afterlife of her crime has been veiled in pretence, the "fantasteri", in which she has taken such great pleasure. She takes pride in the work that she has performed, hidden from Helmer. She finds dignity in knowing that it was she who saved him. Such is her attraction to the game of pretence that she will rather keep up the illusion than go to Torvald - whom she loves and, at least so she says, fully trusts will save and protect her - when Krogstad threatens to reveal her crime. Perhaps, we might wonder, is it as much the illusion of Helmer' ideals as the illusion of the nobility of her crime tha she does not want exposed?

For an answer, we may look to Mrs Johann Luise Heiberg's (1812-90) essay "Is the Art of Acting a Morally Justified Art?" (Er skuespilkunsten en moralsk berettiget kunst?) where Mrs Heiberg emphasizes the need for the female actress to keep up her everyday role as housewife in order to maintain her human dignity and individuality so as to not be lost in the theatre's world of imagination: "To make a home, that is a mission, of which no woman may let herself miss out on, whatever her spiritual talent may lead her to, for no mission for the woman is greater than that. If she achieves this alongside any art, to which she submits herself, then she can, even as an actress, fully preserve her human dignity, her individuality; if she gives this up, then she becomes an excellent doll that everybody plays with - until they get bored with it, and the doll is thrown into a corner, forgotten by all. But you should let nobody play with you. You should respect yourself, when you want others to respect you. ${ }^{\text {"40 }}$ By performing in a marriage of fiction and fantasies rather than an authentic marriage, Nora has indeed become the doll, a doll that Helmer rejects precisely when she can no longer play the part. In a Kierkegaardian sense, Helmer and Nora live in the "imaginative intuition" (Phantasi-anskuelsen), ${ }^{41}$ rather than in authentic lives.

The ideals and standards that Helmer - and Nora - imagine as his principal qualities are false. Helmer conjures up fantasies of himself risking his life in rescuing Nora from an imminent danger: "Oh, my darling wife, I can't hold you close enough. You know, Nora... many's the time I wish you were threatened by some terrible danger so I could risk everything, body and soul for your sake." (p. 74). However, when the fantasy turns reality, Helmer' idealism is exposed as a mask, and he a cynical "monster of egotism" as Herman Bang (1857-1912) characterized him. ${ }^{42}$ The Romantic hero that Nor so desires to see in Helmer fails to come to her rescue. As Bang writes: “'The wonderful' to Nora is the ideal, and her ideal is again the true marriage." ${ }^{13}$ "The wonderful", does not happen. Helmer thinks only of saving himself. Instead, Helmer's "spiritual wretchedness" is exposed: "and when we then slowly but surely see this veil of decency fall, the monster of egotism uncovered and the mask come off, so that we see Helmer's spiritual wretchedness, then the poet will have achieved his goal, exactly because by making the wretchedness bourgeois decent, he forces us to see ourselves in the guise of Thorvald Helmer." ${ }^{44}$ In the failure of Helmer, the backbone of Idealism, the ideal of truth and decency is broken, and significantly, as Bang notes, the failure of Helmer points to the audience.

When Helmer fails to fulfil her fantasy of the wonderful, Nora must see her ideals that she had imagined in Helmer and their marriage, her ideal of the wonderful fall to pieces. The magical romantic idea, the wonderful, is exposed by Ibsen not as an ideal, but as an illusion. The wonderful, a word which in various forms is repeated throughout the play, again gives us a direct reference to the world of Romanticism and Idealism. Thus writes Brandes, paraphrasing a German study by Hermann Petrich (1845-1933): "Therefore, Romanticism is fond of all direct and indirect terms for the wonderful. Such words are: fantastic, admirable [German: bewundernswert], eternal; secret, secretive, holy, heavenly, mysterious, enchanting, enigmatic; unimaginable, spontaneous, unknown; infinite, invisible, inexpressible; strange, amazing, wonderful, miraculous. - Wonder, wondering, marvel, miracle, miracle-working, flower-of-wonder, wunderkind." ${ }^{45}$ Thus we may see Ibsen's breakdown of the wonderful as a semantic deconstruction of the language of Romanticism.

It was this romantic world that Helmer and Nora had cherished in their marriage: wonderful ideals, secret fantasies, enchanting exotic dances, holy mother- and wifehood. Ibsen in A Doll's House exposes the notion of the wonderful as an illusion which is not inherent in, and indeed has nothing to do with, reality. For both Nora and Helmer, the ideals that they had set up for themselves are exposed as figments of the imagination.

Deception is a trait that lies at the core not only of Helmer and Nora, but of every single character of the play. In Krogstad's forgery, Rank's hidden feelings for Nora, Kristine's marriage to a man she didn't love. The only exception is found in the character of the nurse with her real affection for Nora, despite the desperate circumstances that forced he to leave her own daughter. The reality of $A$ Dolls House is not a world of wonders and ideals, but a painful and ruthless world where mothers leave their children and where ideals are only masques.

\section{NORA HAS LEFT THE BUILDING}

For both positive and negative reviewers, the third act of the play - and in particular its conclusio was deeply problematic. They simply found the sudden development of Nora's character to be too drastic. The psychological development from the childlike wife to the woman leaving her husband was unrealistic and unexplainable, and the idea of Nora leaving her children was - in the harshes criticism - even unnatural. Nora does not leave her 
home in a state of bewildered confusion or hysteria, slam in the face of an audience accustomed to the which could be psychologically justified, but rath- ideals of a harmless theatre for the 'Helmers'; a theer in an inexplicable calm and composed state, as atre of delightful vaudevilles and idyllic ballets built the reviewer with the signature G. describes it: "It on Idealist aesthetics. That this slamming door, this is difficult to understand why the playwright in this irreconcilable ending provoked such scandal only final part of the play lets Nora act with this calm suggests that in the Scandinavian context realism confidence and superiority when facing her hus- was only in embryo. The many questions left unanband instead of, what would seem more natural, to swered by Ibsen were to be answered by the imaglet her - exactly in a state of haziness and uneasi- ination of the spectator, and it is my proposal that ness - take the step that she does, in despair over these answers should be found in the reality of the

having been deceived in her 'unerring' belief in her spectators, in the on-going aesthetic and ideological husband's love." ${ }^{4}$

Seeing Nora and Helmer as representations of decaying idealism and awakening individualism or realism, rather than wholly psychologically motivated characters, and the play as a confrontation between two struggling ideological positions, the play's conclusion may be less inexplicable. Reviewer P. Hansen employs a quote from Kierkegaard's $E i$ ther/Or (Enten/Eller, 1843) to describe the essence of Nora's ultimate choice: "When all around me has become still, solemn as a starlit night, when the soul is all alone in the world, there appears before it not a distinguished person, but the eternal power itself. It is as though the heavens parted, and the chooses itself - or, more correctly, it accepts itself. The soul has then seen the highest, which no mortal eye can see and which never can be forgotten. The personality receives the accolade of knighthood which ennobles it for an eternity." ${ }^{47}$ According to $P$. Hansen, Nora makes a leap towards the ethical stage in her decision to make a choice that is true to herself "and precisely therefore do the Ideals commend her choice" ${ }^{48}$ Note here how standards of Idealism are still an authority even to Ibsen's supporters. The development of the character of Nora has not come full circle, it is an awakening, and her education is only in its beginning. Nora is not an emancipated woman but a child, albeit a matured child, when she leaves Helmer. Thus writes an anonymous reviewer: "It is very much a fine psychological poin that she, with no hesitation, lets the decision depend on this vague, half romantic magic, which the expectation of 'the wonderful' signifies, instead of seizing the confrontation as a duty, as a battle, of which she can come out as a genuine and rejuvenated wife." ${ }^{49}$ Nora's slamming of the door was a transition, rather than exclusively within the limit of the fictive universe. That it is up to the spectator to mature and seize the confrontation that our anonymous reviewer lacks in Nora.

If Peer Gynt was "the lie that evades life", ${ }^{50}$ as Georg Brandes stated, Nora may be seen as the disrobed lie that leaves the world of imagination, fantasteriet, delusion, to enter life - as imagined by the spectator. The hope of salvation that $A$ Doll's a free-thinking and educated individual: and with that, the suggestion of a hope for the resurgence of society. Even positive reviewers, such as Edvard Brandes, had, however, little hope for such a turn: "Predictions are always silly, but I still dare to predict that $A$ Doll's House will not become a box-office success. It is too serious. Our aesthetic audience will praise the Helmerian views, and find the play unlovely and immoral. Henrik Ibsen must console ful work of art of a shocking truth." ${ }^{51}$ The correspondence of so-called 'Helmerian views' and the (aesthetic) views of the audience should once more be noted.

Analyzing $A$ Doll's House as both a commentary on a budding Scandinavian aesthetic and ideologica argument of a waning and an emerging concept of imagination exposeses a marked positioning of the spectator, who is, on the one hand, confronted with the exposing of the wonderful - the ideal - as an

illusion and the disenchanting the imagination; the other hand, invited to conclude in reality that which is left unfinished in the realm of the fiction.

In a wider context, the defeat of Idealism did come to mean the downfall of imagination. In time of growing industrialization, of major techniHouse offers lies in the potential rebirth of Nora a himself with the fact that he has created a power- cal and scientific advances, the academic focus shifted from philosophy to science. Indeed, there would be no substantial study devoted to the subject of imagination until 1936 with the publication of JeanPaul Sartre's Limagination. In Sartre's view, imagination was to be radically conceived as an essential nothingness. On the stage, however, imagination was soon to be revived with symbolist drama, including the later dramas by Ibsen himself, and thus, the disenchanted imagination became a reimagined imagination. 


\section{NOTES AND REFERENCES}

1 See e.g. M. H. Abrams, The Mirror and the Lamp: Romantic Theory and the Critical Tradition, Oxford University Press, London 1971.

2 This is the tenet of, amongst others, philosopher Friedrich Wilhelm Joseph von Schelling, for whom art was the highest means of bridging the gap between the infinite and the finite, see Friedrich Wilhelm Joseph von Schelling, "System Des Transzendentalen Idealismus" in Schellings Werke, vol. II, C. H. Beck, München 1965, p. 630.

3 Nicolai Wergeland, Retfardig Bedommelse Af Henrik Wergelands Poesie Og Karakter, Gyldendal, Oslo 1995, p. 53. My translation.

4 Carl Henrik Koch, Den Danske Idealisme 1800-1880, Gyldendal, København 2004, p. 141. My translation.

5 Cited in Frederik Schyberg, Dansk Teaterkritik, Gyldendal, København 1937, p. 170

6 Quoted in Dansk Litteraturs Historie, vol. 2, Sune Auken et al., eds., Gyldendal, København 2008, p. 42. My translation.

7 Cited in Robert Neiiendam, Det Kongelige Teaters Historie, vol. III, Pios Boghandel, København 1925, p. 53. My translation.

8 Petersen continues: "Therefore it is not, as handicraft can be, pure reproduction, no, the human spirit must always have put its creative, idealising touch on that which deserves the name artwork. The ideality of art is beauty, because beauty is the natural expression of goodness in external forms. Therefore, where art portrays ugliness, it is not the real ugliness, but the idealising one." Fredrik Petersen, "Henrik Ibsen's Drama $A$ Doll's House" in $A f$ tenbladet, 9 and 10 January 1880. National Library of Norway, http://ibsen.nb.no/id/11186647.0 (accessed 5 January 2014)

9 Georg Brandes, "Adam Oehlenschläger: Aladdin" in Samlede Skrifter, vol. I, Gyldendalske Boghandels Forlag (F. Hegel \& Søn), Kjøbenhavn 1899, p. 236. Brandes continues: "for he, who was the emperor of the kingdoms of wish and reverie, was in Denmark for long times in fact $[\ldots]$ considered the quintessence of al truth and all right." My translation.

10 Ibid., p. 215.

11 Ibid.

12 Ibid., p. 230

13 Ibid., p. 242.

14 Ibid., p. 243.
15 Søren Kierkegaard, The Sickness Unto Death, Princeton University Press, Princeton, N. J. 1980, p. 31.

16 Søren Kierkegaard, Training in Christianity, Princeton University Press, Princeton 1967, p. 190.

17 Ibid., p. $185 f$.

18 Ibid., p. 186.

19 Richard Kearney, The Wake of Imagination: Toward Postmodern Culture, Routledge, London 1998, p. 188. 20 Ibid., p. 185

21 Richard Sha, "Toward a Physiology of the Romantic Imagination" in Configurations, vol. 17, 2009, p. 13.

22 Georg Brandes, "Fantasien Og Livet" in Samlede Skriffer, Gyldendalske Boghandels Forlag, Kjøbenhavn 1905, p. 486. My translation.

23 The director of the Royal Theatre, Edvard Fallesen, had, when failing to hinder the publication of the text prior to the premiere, managed to persuade the Danish reviewer to stall all reviews of the published text. In consequence, there is little distinction in these reviews between text and performance.

24 Edvard Brandes, "Henrik Ibsen's $A$ Doll's House at the Royal Theatre" in Ude og Hjemme, vol. 3, no. 118, January 1880. National Library of Norway, http://ibsen. nb.no/id/11195169.0 (accessed 5 January 2014).

25 Erik Vullum, "Henrik Ibsen: A Doll's House, Play in Three Acts. Copenhagen, Gyldendal Publishers (Gyldendalske Boghandels Forlag), 1879" in Literatur-Tidende, 6 and 13 December 1879. National Library of Norway, http:// ibsen.nb.no/id/11186623.0 (accessed 5 January 2014)

26 As the anonymous reviewer in Bergens Tidende somewhat optimistically notes: "'Realism in our time has triumphed everywhere in the visual arts and literature alike, and albeit Romanticism still here and there has a lonely representative, you strongly feel that its voice is but a weak reverberation of a movement, whose missio has been fully completed." In "Henrik Ibsen, Et Duk kehjem. Skuespil i Tre Akter. (Kjøbenhavn. Gyldendalske Boghandels Forlag)" in Bergens Tidende, vol. 12, no. 294A \& 295A, 18 and 19 December 1879. Nation Library of Norway, http://ibsen.nb.no/id/11180390.0 (accessed 5 January 2014). My translation.

27 See e.g. Petersen, op. cit.

28 Amalie Skram, "A Reflection on A Doll's House" in Dagbladet, vol. 12, no. 15, 19 January 1880. National Library of Norway, http://ibsen.nb.no/id/11186656.0 (accessed 5 January 2014). The full entry reads: "the Helmers of this world, who are bourgeois society's in- dividualized incarnation of self-righteous mercilessness, will continue to throw stones at the Noras throughour history, and society's mob will likewise always probably assist them."

29 Robert Neiiendam, op. cit., p. 58.

30 Vullum, op. cit. See also Skram op. cit. "Each character is a genuine type, originated in its own generation, sprung out of the times, and fallen as a ripe fruit of its own natout of the times, and fallen as a ripe f
uralistic and psychological necessity."

31 See e.g. Edvard Brandes, Dansk Skuespilkunst, P. G. Philipsens Forlag, København 1880, p. 233. There Brandes characterizes Hennings' roles as Nora and before that Signe in Bjørnstjerne Bjørnson's A Bankruptcy (En Fallit, 1874) as reactions against the ingénue.

32 See e.g. Fritz Wefelmeyer, "Raphael's Sistine Madon na: An Icon of the German Imagination from Herder to Heidegger" in Text into Image: Image into Text, Jeff Morrison and Florian Krobb, eds., Rodopi, Amsterdam 1997.

33 See Joe Perry, Christmas in Germany: A Cultural History, University of North Carolina Press, Chapel Hill 2010. 34 Vullum, op. cit.

35 See e.g. Erik Østerud "A Doll's House: Ibsen's Italian Masquerade" in Theatre Studies, vol. 10, 1997, pp. 2335.

36 Henrik Ibsen, A Doll's House, James Walter McFarlane trans., in Four Major Plays, Oxford University Press, Oxford 2008, p. 15. All subsequent references to the play will, unless otherwise indicated, refer to this edition.

37 Edvard Brandes, "Henrik Ibsen's $A$ Doll's House at the Royal Theatre".

38 Henrik Ibsen, Four Major Plays: A Doll House, The Wild Duck, Hedda Gabler, The Master Builder, Rolf Fjelde, trans., New American Library of World Literature, New York 1965

39 A characterization of Aladdin as a "lucky child" is, for example, found in H. C. Andersen's novel Lykke-Peer (1870). Later, in Henrik Pontoppidan's novel of the same title, Lykke-Per (1898-1904), the portrait of the child of fortune was rendered from a more sceptical, problematizing point of view.

40 Johanne Luise Heiberg, "Er Skuespilkunsten En Moralsk Berettiget Kunst?" in Et Liv Gjenoplevet i Erindringen Aage Friis, ed., Gyldendal, København 1944, p. 160.

41 See e.g. Søren Kierkegaard, Om Begrebet Ironi, Søren Kierkegaard Forskningscenteret, Gads Forlag, København 1997, p. 326
42 Herman Bang, Realisme og Realister: Kritiske Studier og Udkast, Det danske Sprog- og Litteraturselskab, Borgen, København 2001, p. 360. http://www.adl.dk/ adl_pub/pg/cv/ShowPgImg.xsql?nnoc=adl_pub\&p_ udg_id=192\&_p_sidenr=1, (accessed 6 January 2014). My translation.

43 Ibid., p. 359

44 Ibid., p. 360

45 Georg Brandes, "Adam Oehlenschläger: Aladdin", op cit., p. 219. Brandes cites Hermann Petrich, Drei Kapitel Vom Romantischen Stil, Otto Zeller, Osnabrück 1964, as his source. In Chapter 3, "Die Mystik des romantischen Stils", Petrich meticulously accounts for the statistical prevalence of "die directe Bezeichnung des Wunderbaren" (p. 101), e.g. Wunder-, Zauber-, Geheimnis-, Seltsam-.

46 G., "Henrik Ibsen: Et Dukkehjem", Bergens Aftenblad, vol. 1, no. 1, 2 January 1880. National Library of Norway, http://ibsen.nb.no/id/11180486 (accessed 5 January 2014). My translation.

47 Quoted from Søren Kierkegaard, Either/Or, Alastair Hannay, trans., Penguin Books, London 1992, p. 491. See further P. Hansen, "Et Dukkehjem og Recensenterne” in Kristianssands Stiftsavis og Adressekontors-Efterretninger vol. 91, no. 16, 17 and 18A; 7, 10 and 12 February 1880

48 Hansen, op. cit. My translation.

49 Anonymous, op. cit.

Georg Brandes, "Adam Oehlenschläger: Aladdin", op cit., p. 242

51 Edvard Brandes, op. cit. 